\title{
BIOFILM FORMATION OF Vibrio cholerae ON STAINLESS STEEL USED IN FOOD PROCESSING
}

\author{
Milagro FERNÁNDEZ-DELGADO(1), Héctor ROJAS(2), Zoilabet DUQUE(3), Paula SUÁREZ(4), Monica CONTRERAS(1), \\ M. Alexandra GARCÍA-AMADO(1) \& Carlos ALCIATURI(3)
}

\begin{abstract}
SUMMARY
Vibrio cholerae represents a significant threat to human health in developing countries. This pathogen forms biofilms which favors its attachment to surfaces and its survival and transmission by water or food. This work evaluated the in vitro biofilm formation of $V$. cholerae isolated from clinical and environmental sources on stainless steel of the type used in food processing by using the environmental scanning electron microscopy (ESEM). Results showed no cell adhesion at $4 \mathrm{~h}$ and scarce surface colonization at $24 \mathrm{~h}$. Biofilms from the environmental strain were observed at $48 \mathrm{~h}$ with high cellular aggregations embedded in Vibrio exopolysaccharide (VPS), while less confluence and VPS production with microcolonies of elongated cells were observed in biofilms produced by the clinical strain. At $96 \mathrm{~h}$ the biofilms of the environmental strain were released from the surface leaving coccoid cells and residual structures, whereas biofilms of the clinical strain formed highly organized structures such as channels, mushroom-like and pillars. This is the first study that has shown the in vitro ability of V. cholerae to colonize and form biofilms on stainless steel used in food processing.
\end{abstract}

KEYWORDS: Vibrio cholerae; Biofilms; Stainless steel; Food processing; Environmental scanning electron microscopy.

Vibrio cholerae, the causative agent of cholera, is a facultative pathogen having both human and environmental stages. $V$. cholerae epidemics typically result from the consumption of contaminated drinking water or food. One key factor for $V$. cholerae environmental survival and transmission is its ability to form biofilms ${ }^{1}$, defined as assemblages of microbial cells surrounded by exopolysaccharides, and for $V$. cholerae it is called Vibrio exopolysaccharide (VPS). Biofilms enhance growth and survival of bacteria providing access to nutrients and protection from toxic compounds, thermal stress, and predation ${ }^{2}$. The developmental cycle begins with the attachment of single or aggregated cells to a surface followed by microcolony formation, VPS synthesis and excretion to the extracellular medium, subsequent formation of organized 3D structures ${ }^{3,4}$ and finally, detachment and dispersion of cells to colonize new areas ${ }^{5}$.

The main microscopic techniques that have been developed to study $V$. cholerae biofilms are the confocal scanning laser microscopy on glass surfaces and the scanning electron microscopy $(\mathrm{SEM})^{2}$ on organic or inorganic surfaces. Sample preparation for SEM may compromise the biofilm morphology or introduce artefacts ${ }^{6}$. The environmental scanning electron microscopy (ESEM), a special variant of SEM, has been used to visualize biofilms of other bacteria in their natural state with minimum damage ${ }^{7}$.

Numerous studies have investigated $V$. cholerae biofilms on biotic (phytoplankton and zooplankton) ${ }^{4}$ and abiotic surfaces (plastic, glass and ballast tanks of ships $)^{8,9,10}$. However, there is a lack of knowledge of these biofilms on stainless steel surfaces often used in food-processing environments ${ }^{11}$. Despite the efforts to improve the hygiene in food processing, V. cholerae still represents a significant threat to human health in developing countries ${ }^{12}$. Therefore, this study aimed to evaluate the in vitro biofilm formation of $V$. cholerae from clinical and environmental origins on stainless steel used in food processing as potential colonization surface by using ESEM.

Stainless steel (grade 304, UNS S30400) $1 \mathrm{~cm}^{2}$ coupons were used as the adhesion surface. Grade 304 is one of the most commonly used food contact surface because of its chemical and mechanical/physical stability at various food-processing temperatures, cleanability and high resistance to corrosion ${ }^{11}$. Coupons were prepared by immersion in dichloromethane for $5 \mathrm{~min}$ (Sigma-Aldrich) and subsequently in ethanol 100\% with gentle sonication in an ultrasonic bath sonicator (5-10 $\mathrm{min}$ ) at 30\% of amplitude, 750 W, 20 KHz (Cole-Parmer Instruments).

Two strains of $V$. cholerae were evaluated regarding the biofilm formation on stainless steel. A clinical strain of toxigenic V. cholerae O1, serotype Ogawa, biotype El Tor, obtained from the Centro Venezolano de Colecciones de Microorganismos (CVCM 306, http://www.wfcc. info/ccinfo/index.php/collection/by_id/815/, Caracas, Venezuela), was isolated during the 1990's cholera epidemic from the stool sample of a patient, and cultured in Luria Bertani medium at the clinical laboratory

(1) Instituto Venezolano de Investigaciones Científicas (IVIC), Laboratorio de Fisiología Gastrointestinal, Centro de Biofísica y Bioquímica. Caracas, Venezuela.

(2) Universidad Central de Venezuela, Instituto de Inmunología. Caracas, Venezuela.

(3) Instituto Zuliano de Investigaciones Tecnológicas (INZIT), Unidad de Biodeterioro Industrial. Estado Zulia, Venezuela.

(4) Universidad Simón Bolívar (USB), Departamento de Biología de Organismos, Laboratorio de Microbiología Acuática. Caracas, Venezuela.

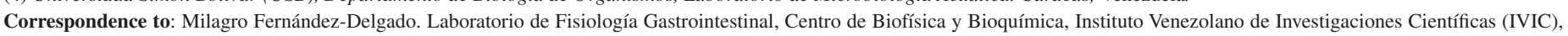
Km 11 carretera Panamerica, 1020A Caracas, Venezuela. Phone: +58-212-5041468. Fax: +58-212-5041093. E-mail: milagrof@ivic.gob.ve 


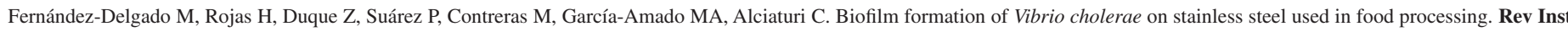
Med Trop Sao Paulo. 2016;58:47.

service, School of Bioanalysis, Universidad Central de Venezuela, Caracas. The second strain was isolated from seawater collected in a recreational area of the North Western Venezuelan Caribbean coast during an unusually heavy and long rainy period that occurred in December 2004. This environmental strain (CVCM 1742) was initially cultured using the HP selective medium, purified in thiosulfate-citrate-bile salts-sucrose agar (TCBS, Merck) and identified by biochemical, serological and molecular tests as $V$. cholerae non-O1, non-O139, non-toxigenic (negative to $\operatorname{ctxA}$ and $c t x B$ genes), but carrying antibiotic resistance ${ }^{13}$. Both $V$. cholerae strains were grown in TCBS agar at $37^{\circ} \mathrm{C}$ for $24-48 \mathrm{~h}$. Bacterial inocula to be used in the biofilm assays were prepared collecting one loopful from the TCBS agar, suspended in Nutrient Broth (HiMedia) and incubated at $37^{\circ} \mathrm{C}$ until reaching the logarithmic phase. Viable cell concentrations of clinical $\left(2.84 \times 10^{4}\right.$ cells $\left./ \mathrm{mL}\right)$ and environmental $\left(5.72 \times 10^{4}\right.$ cells $\left./ \mathrm{mL}\right)$ inocula were estimated using the LIVE/DEAD BacLight kit (Invitrogen). Aliquots of suspended cells $(0.5 \mathrm{~mL})$ were inoculated in Nutrient Broth vials $(4.5 \mathrm{~mL})$ containing sterile coupons and incubated at $37{ }^{\circ} \mathrm{C}$ for 4 , 24, 48 and $96 \mathrm{~h}$ in quadruplicate. Vials without inocula were included as controls. The coupons were removed, rinsed three times with sodium cacodylate buffer ( $0.1 \mathrm{M}, \mathrm{pH} 7.4)$, immersed in $2.5 \%$ glutaraldehyde and kept at $4{ }^{\circ} \mathrm{C}$ until ESEM analysis ${ }^{14}$. Micrographs were obtained using a Quanta 200FEG ESEM (FEI Company) with acceleration voltage and chamber pressure of 4-6 kV and 130-190 Pa, respectively. Representative images were chosen from 15 random positions for each sample.

This study evaluated by ESEM the biofilm development of clinical and environmental $V$. cholerae strains on stainless steel during a time course of 4-96 h. The results showed the evolution since a few cells adhered to steel, until formation of highly structured biofilms with 3D arrangements in the case of the clinical strain and final detachment in the case of the biofilms produced by the environmental strain. Coupons' surfaces exhibited no bacterial adhesion at $4 \mathrm{~h}$, showing only characteristic parallel grooves (Fig. 1a, e). Few cells were observed at
$24 \mathrm{~h}$, indicating a slow colonization of the surface by both strains (Fig. $1 \mathrm{~b}, \mathrm{f})$. Biofilms from the environmental strain grew faster with higher aggregation embedded in amorphous and smooth VPS overproduction at $48 \mathrm{~h}$ (Fig. 1g), contrasting with a less confluence observed for the biofilm produced by the clinical strain (Fig. 1c). Biofilms from the environmental strain were released at $96 \mathrm{~h}$, leaving some coccoid cells and small residuary structures (Fig. $1 \mathrm{~h}$ ); meanwhile the clinical strain displayed dense biofilms with crystalline-like VPS at 96 h (Fig. 1d). Differences found in the VPS production, development and detachment of biofilms for both strains might be explained by the bacterial origins or by their innate adaptive strategies under similar culture conditions. The biofilm cycle of the environmental strain displayed a higher growth and a faster detachment than the clinical strain, probably due to a more favourable environmental set in our experimental conditions rather than the aquatic ecosystem from which the strain was isolated. Additionally, the presence of coccoid cells attached to the stainless steel surface was notorious in the detachment process of the environmental biofilm. A previous work showed the ability of this strain to enter a coccoid or viable but non-culturable (VBNC) state as an adaptation to survive under starvation conditions ${ }^{15}$. The earlier detachment of environmental biofilms (Fig. $1 \mathrm{~h}$ ) could be due to nutrients depletion that occurred up to $96 \mathrm{~h}$, acting as an external signal in the regulation of $V$. cholerae biofilm formation ${ }^{16}$. Conversely, the biofilms of the clinical strain remained on stainless steel at $96 \mathrm{~h}$, without an apparent dispersal (Fig. $1 \mathrm{~d}$ ), indicating a lower rate of development to reach the last stage of the biofilm cycle. Our experimental conditions differ from the rich nutrient environment of the human intestine and could have delayed the biofilm development cycle. Further studies should evaluate longer periods of biofilm formation.

In Figure 2, the clinical strain was observed with intertwined elongated cells in division $(20-50 \mu \mathrm{m})$, forming microcolonies after 48 h, and biofilms covered by VPS at 96 h (Fig. 2a-d). Elongated cells have been described as a survival adaptation to nutrient-poor conditions ${ }^{17}$.

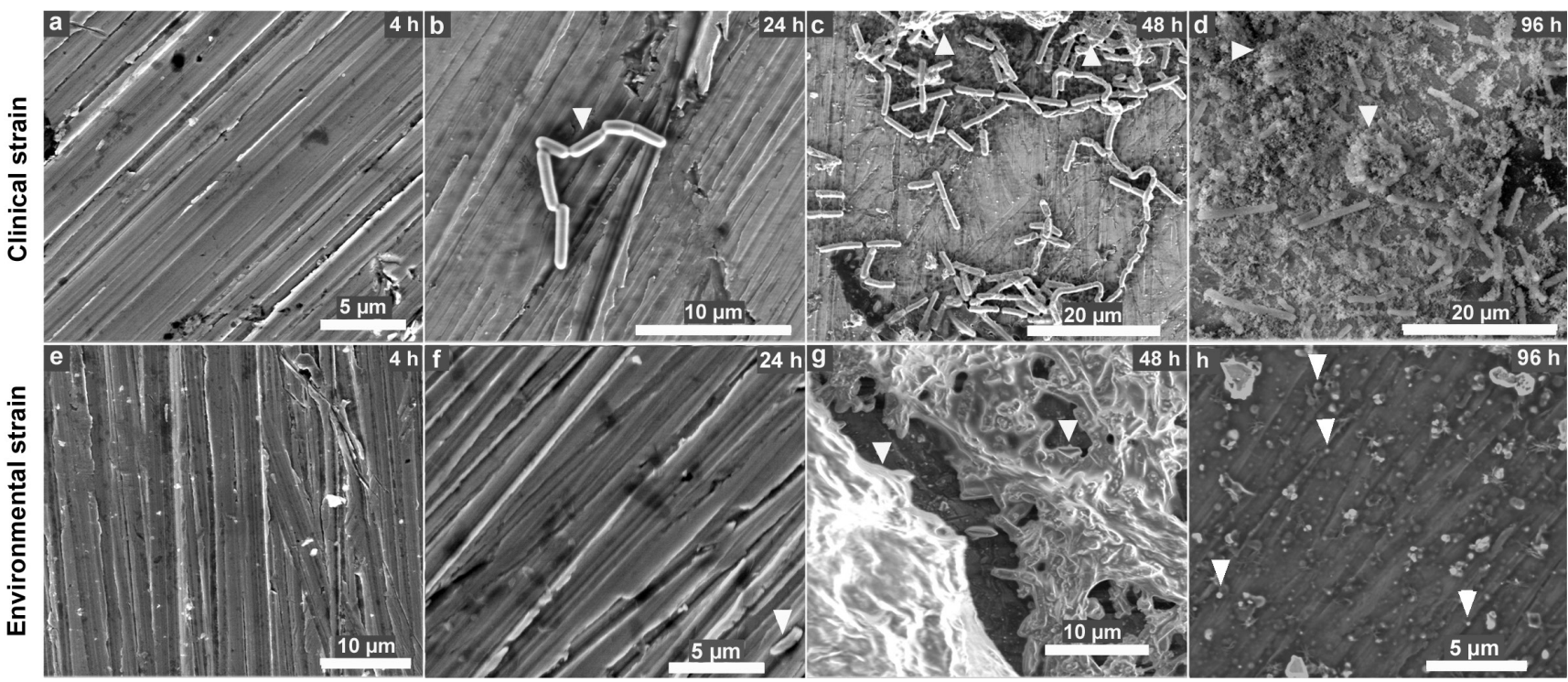

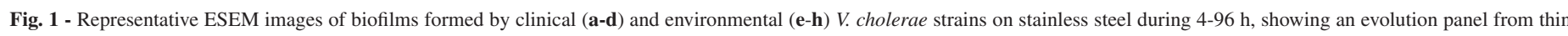

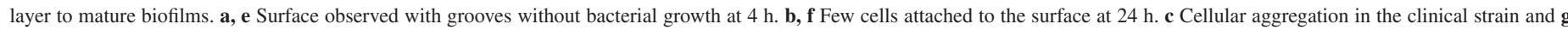

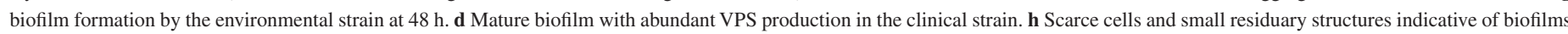
detachment. Head arrows indicate differences in biofilm formation for each case. 


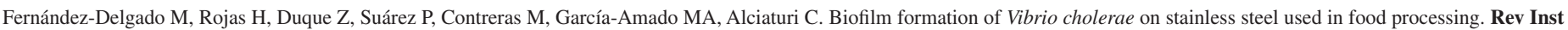
Med Trop Sao Paulo. 2016;58:47.

Nutritional conditions present in stainless steel would not favour the biofilm development before $48 \mathrm{~h}$. In addition, highly organized structures like channels, mushrooms and pillars were found later, up to $96 \mathrm{~h}$ (Fig. 2e-h). Biofilm 3D structures have been reported regarding V. cholerae ${ }^{4}$. These structures are composed of pillars surrounded by water channels that allow nutrients to reach biofilm-associated bacteria and toxic metabolites to diffuse to the outside of biofilms ${ }^{3}$. A previous study of $V$. cholerae biofilms reported pillar-like structures and channels formed on chitin $(\sim 20 \mu \mathrm{m})^{18}$ with a higher rate and in less time than the same formations observed on stainless steel in our study $(\sim 5-10 \mu \mathrm{m})$. The mushroom-like formation has not been previously observed in the case of $V$. cholerae biofilms. This structure was reported in Pseudomonas aeruginosa and is believed to allow the passage of nutrients to bacteria from the upper to the deeper levels of biofilms ${ }^{19}$. In surfaces such as chitin, $V$. cholerae biofilms obtain the carbon and nitrogen from the biotic surface ${ }^{18}$. By contrast, under our experimental conditions and using the stainless steel substrate, nutrients are incorporated from the culture medium and through the development of mushroom-like structures. On the other hand, biofilms from the environmental strain showed irregularshaped rods $(2-10 \mu \mathrm{m})$ with some 'round bodies' covered with VPS in 48 $\mathrm{h}$ (Fig. 3a). A rounded cell reduced in size was clearly observed at this time (Fig. 3b). A high number of tiny coccoid cells $(0.1-0.7 \mu \mathrm{m})$ with and without strand-like structures were found dispersed or rearranged into small clusters at $96 \mathrm{~h}$ when the biofilm detachment occurred (Fig. 3c, d). Coccoid cells could eventually enter a VBNC state described as a survival strategy to environmental constraints whereby cells are reduced in size and volume, exhibiting detectable metabolic functions ${ }^{20}$. Similar morphologies have been reported in stressed $V$. cholerae cells under

\section{Clinical strain}

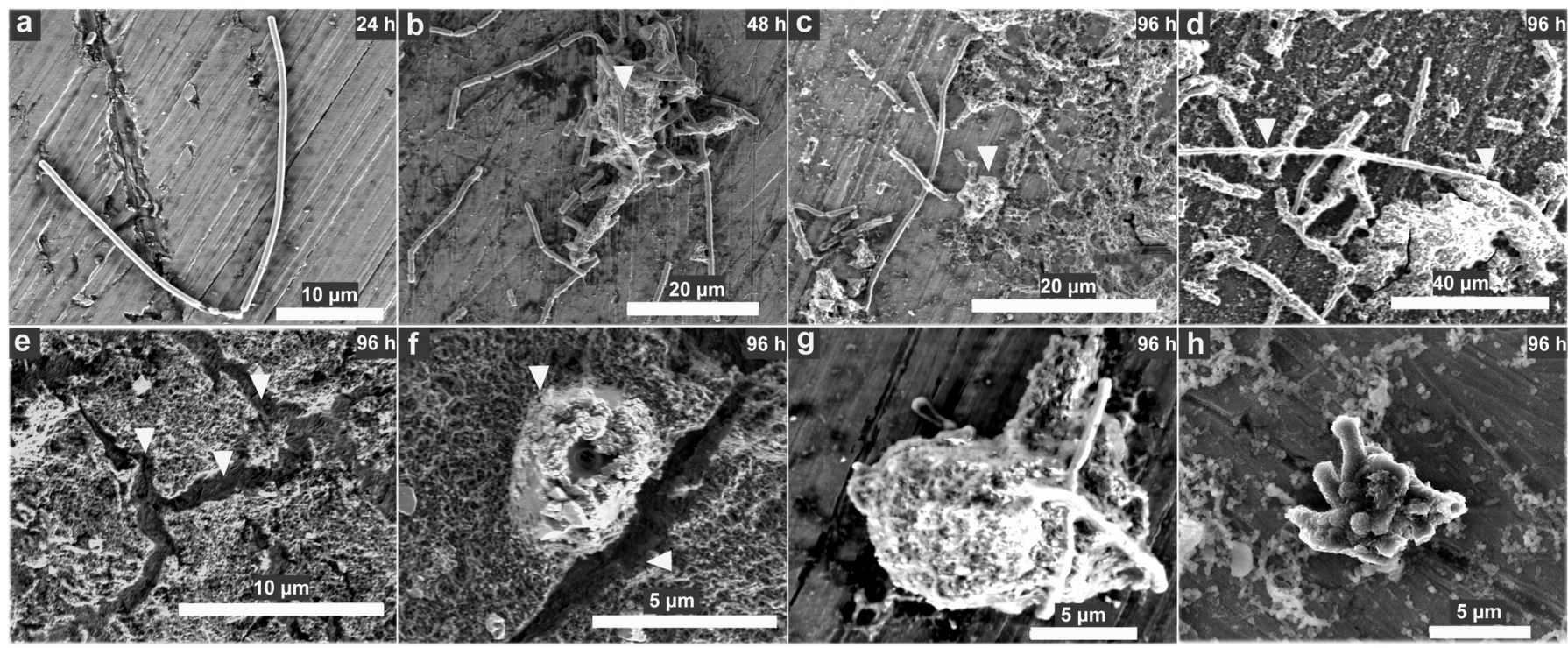

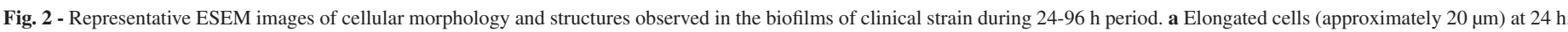

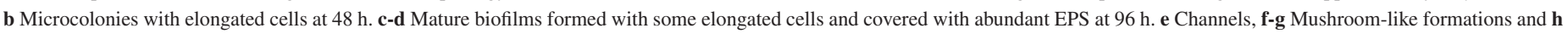
pillars found in biofilms at $96 \mathrm{~h}$. Head arrows indicate cellular forms or biofilm structures.
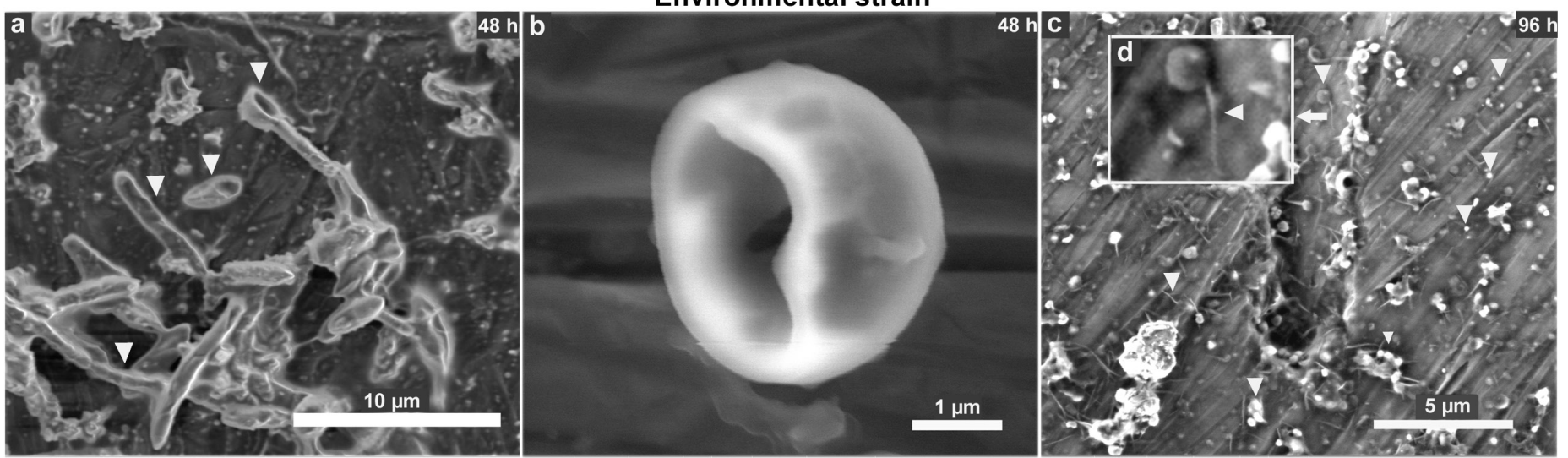

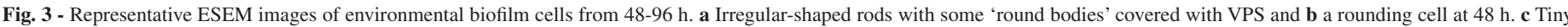
coccoid cells and cells with strand-like structures (insert d) at $96 \mathrm{~h}$. Head arrows indicate cellular forms. 
Fernández-Delgado M, Rojas H, Duque Z, Suárez P, Contreras M, García-Amado MA, Alciaturi C. Biofilm formation of Vibrio cholerae on stainless steel used in food processing. Rev Inst Med Trop Sao Paulo. 2016;58:47.

nutrient-poor conditions and prolonged periods ${ }^{17,20}$. Moreover, these cells have been associated to biofilms, suggesting a critical role in the pathogen transmission ${ }^{2,4}$.

This is the first study that shows in vitro the ability of this bacterium to colonize and form mature biofilms on stainless steel with substantial differences between clinical and environmental strains regarding the morphology, VPS production and developmental time. Our findings evidenced cellular forms, 3D and novel structures, setting the basis for future studies using ESEM. The present work contributes to the current knowledge of $V$. cholerae biofilms and would be helpful to assess and control the public health risk associated with the potential colonization of this bacterium on stainless steel used in the food industry.

\section{ACKNOWLEDGEMENTS}

Authors gratefully acknowledge to K. Balzan, H. Inciarte and E. Plaza from INZIT for their technical assistance with fluorescent microscopy and ESEM, and R.N. Incani and M. López Gasca for English improvements of the manuscript. This work was partially funded by grants from INZIT to Z.D., Decanato de Investigación y Desarrollo of USB to P.S. and IVIC to M.F., M.C. and M.A.G.

\section{AUTHOR CONTRIBUTIONS}

M. Fernández-Delgado: experimental procedures, results analysis and manuscript preparation. H. Rojas: results analysis and manuscript preparation. Z. Duque: experimental procedures and results analysis. P. Suárez, M. A. García-Amado, M. Contreras and C. Alciaturi: results analysis.

\section{REFERENCES}

1. Yildiz FH, Visick KL. Vibrio biofilms: so much the same yet so different. Trends Microbiol. 2009;17:109-18.

2. Huq A, Whitehouse CA, Grim CJ, Alam M, Colwell RR. Biofilms in water, its role and impact in human disease transmission. Curr Opin Biotechnol. 2008;19:244-7.

3. Costerton JW, Lewandowski Z, Caldwell DE, Korber DR, Lappin-Scott HM. Microbial biofilms. Annu Rev Microbiol. 1995;49:711-45.

4. Yildiz FH. Processes controlling the transmission of bacterial pathogens in the environment. Res Microbiol. 2007;158:195-202.

5. Davey ME, O'Toole GA. Microbial biofilms: from ecology to molecular genetics. Microbiol Mol Biol Rev. 2000;64:847-67.

6. Collins SP, Pope RK, Scheetz RW, Ray RI, Wagner PA, Little BJ. Advantages of environmental scanning electron microscopy in studies of microorganisms. Microsc Res Tech. 1993;25:398-405.
7. Schwartz T, Jungfer C, Heibler S, Friedrich F, Faubel W, Obst U. Combined use of molecular biology taxonomy, Raman spectrometry, and ESEM imaging to study natural biofilms grown on filter materials at waterworks. Chemosphere 2009;77:24957.

8. Drake LA, Doblin MA, Dobbs FC. Potential microbial bioinvasions via ships' ballast water, sediment, and biofilm. Mar Pollut Bull. 2007;55:333-41.

9. Shikuma NJ, Hadfield MG. Marine biofilms on submerged surfaces are a reservoir for Escherichia coli and Vibrio cholerae. Biofouling. 2010;26:39-46.

10. Watnick PI, Kolter R. Steps in the development of a Vibrio cholerae El Tor biofilm. Mol Microbiol. 1999;34:586-95.

11. Houdt V, Michiels CW. Biofilm formation and the food industry, a focus on the bacterial outer surface. J Appl Microbiol. 2010;109:1117-31.

12. Vengadesh L, Son R, Yoke-Kqueen C. Molecular quantification and characterization of Vibrio cholerae from different seafood obtained from wetmarket and supermarket. Int Food Res J. 2012;19:45-50.

13. Fernández-Delgado M, García-Amado MA, Contreras M, Edgcomb V, Vitelli J, Gueneau P et al. Vibrio cholerae non-O1, non-O139 associated with seawater and plankton from coastal marine areas of the Caribbean Sea. Int J Environ Health Res. 2009;19:279-89.

14. Holling N, Dedi C, Jones CE, Hawthorne JA, Hanlon GW, Salvage JP, et al. Evaluation of environmental scanning electron microscopy for analysis of Proteus mirabilis crystalline biofilms in situ on urinary catheters. FEMS Microbiol Lett. 2014;355:20-7.

15. Fernández-Delgado M, García-Amado MA, Contreras M, Incani RN, Chirinos H, Rojas $\mathrm{H}$, et al. Survival, induction and resuscitation of Vibrio cholerae from the viable but nonculturable state in the southern Caribbean Sea. Rev Inst Med Trop Sao Paulo. 2015;57:21-6.

16. Teschler JK, Zamorano-Sánchez D, Utada AS, Warner CJ, Wong GC, Linington RG, et al. Living in the matrix: assembly and control of Vibrio cholerae biofilms. Nat Rev Microbiol. 2015;13:255-68.

17. Jubair M, Morris JG Jr, Ali A. Survival of Vibrio cholerae in nutrient-poor environments is associated with a novel "persister" phenotype. PLoS One 2012;7:e45187.

18. Fernández-Delgado M, Suárez P, Duque Z, García-Amado MA, Contreras M. Supervivencia y formación de biopelículas de Vibrio cholerae sobre quitina de camarón. Interciencia. 2013;38:443-8.

19. Klausen M, Aaes-Jørgensen A, Molin S, Tolker-Nielsen T. Involvement of bacterial migration in the development of complex multicellular structures in Pseudomonas aeruginosa biofilms. Mol Microbiol. 2003;50:61-8.

20. Chaiyanan S, Chaiyanan S, Grim C, Maugel T, Huq A, Colwell RR. Ultrastructure of coccoid viable but non-culturable Vibrio cholerae. Environ Microbiol. 2007;9:393402.

Received: 19 May 2015

Accepted: 17 November 2015 